\title{
College Of Business Majors' Perceptions Toward Globalization: An Empirical Study
}

Basil Janavaras, Minnesota State University, Mankato

John Kuzma, Minnesota State University, Mankato

Harold Thiewes, Minnesota State University, Mankato

\begin{abstract}
The objective of this paper is to determine the extent to which business majors' attitudes towards globalization are influenced by the area of selected study. Research has documented that more favorable attitudes towards globalization are found among college students, and specifically, these more favorable attitudes are found in business majors. While individuals may see globalization resulting in positive effects for the economy, business and the consumer, attitudes concerning globalization's impact on the environment and domestic job creation and security may be quite different. We surveyed junior and senior students at a mid-western public university on a variety of questions related to globalization. Unlike the comparison of business with liberal arts majors, a further examination of the responses of four different business majors failed to note any consistent differences in the student responses. Our findings support the Heckscher-Ohlin theory which argues that one's skill endowments influence perceptions on globalization, and, when applied to the academic environment, the more favorable global attitudes among business majors are influenced by the skills attained in their academic training.
\end{abstract}

Keywords: Globalization, Student Perceptions, Globalization Survey, Heckscher-Ohlin Theory

\section{INTRODUCTION}

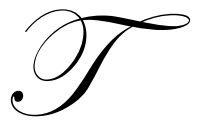

he objective of this paper is to ascertain the extent to which individual university student attitudes towards globalization are influenced by the area of selected study; specifically, we compared the responses of four different business majors with those of liberal arts majors concerning their perceptions of various globalization issues. Joseph Stiglitz (2002), the former chairman of President Clinton's Council of Economic Advisers and 2001 Nobel Prize recipient defined globalization as the

..closer integration of countries and peoples of the world, which has been brought about by the enormous reduction of transportation and communication costs, and the breaking down of artificial barriers affecting the flows of goods, services, capital, knowledge, and people across borders.

However, this term can imply varied meanings to divergent groups. At one extreme, anti-globalization groups would argue that globalization has undermined wages, exploited workers in developing countries and given the multi-national enterprises excessive control and wealth. At the other extreme, the pro-globalization group would argue that globalization has removed barriers for the free flow of goods, services and capital across country borders and fostered a more rapid integration of cultures from around the world. Most economists would argue that protectionism poses a threat to world economies; yet, the economic and financial distress of the 1990s decade, which experienced the 1994 Tequila, the 1997 Asian, and decade-ending Russian economic and financial crises, have caused many to reassess the pace of economic liberalization.

Joseph Stiglitz claimed that the freer movement of capital, goods and services across borders has actually contributed to the financial upheaval experienced by many of the developing countries. Harvard University economist Dani Rodrik questioned the limits of free trade in promoting economic growth, while Princeton 
University economist Helene Rey proposed theories on how emerging markets are prone to crash when opening their financial markets (Hilsenrath, 2002). Despite the problems that the majority of the developing countries experienced when integrating their economies into the global environment, then Secretary-General of the United Nations Kofi Anan, when addressing the 2000 Millennium Forum, still advocated the necessity of globalization: "I believe the poor are poor not because of too much globalization but because of too little" (Annan, 2000). Secretary General Anan expressed this view despite the fact that the developing countries' share of exports, such as agricultural exports has fallen from 31.7\% over 1970-1972 to $26.4 \%$ over 1998-1999 period (Kassum, 2004). Thus, with such noted economists questioning both the impact and pace of globalization, one might also expect students to express varied views and it is highly probable that such views could be influenced by their area of study.

\section{LITERATURE REVIEW}

Statistics tend to support an overall benefit from globalization, even though the allocation of those benefits is questionable. Globalization's intent is to eliminate international differences through the exchange of products and services, information and technology, as well as culture. However, economic integration can result in an unequal distribution of the benefits of globalization. In actuality, global trade grew by $80 \%$ between 1990 and 2000 and the total flow of foreign direct investment increased fivefold, while the world economy increased by a relatively small 23\% (Bernstein, 2000). Critics of globalization would argue that such statistical inequalities indicate that it is the developed countries which gain the larger proportion of benefits, often at the expense of the emerging countries.

The Heckscher-Ohlin theory on globalization predicts that individual and country attitudes towards globalization would be influenced by one's 'skill or factor endowments'. Specifically, the theory attempts to explain trade patterns through the argument that skilled individuals in countries with higher levels of skill endowments would tend to have more favorable attitudes towards trade and globalization relative to those individuals in less skilled or labor intensive countries. Evidence is mixed. Research from the U.S. labor market found that low-skilled individuals were more likely to support import and immigration restrictions than their highskilled counterparts and these personal endowments were more important in explaining trade attitudes than the sector in which the individuals were employed (Scheve and Slaughter, 2001). However, Bowen, Leamer and Sveikauskas (1987) challenged the theory's credibility while others, such as Davis and Weinstein (2001) found data to validate the theory but suggested that country differences are not attributable to factor endowment differences alone.

Although the theory has primarily been used to explain trade patterns, we will apply this theory in an attempt to explain student attitudes towards globalization. At the individual level, we might expect those engaged in more skill-oriented majors to exhibit more favorable views towards globalization issues than those individuals majoring in less-skilled, but conceptually broader majors. Specifically, in contrast to many of the liberal arts majors, business majors are taught more applied and technical skills that are more directly related to their career objectives. We might expect these majors to possess a more favorable view of globalization (O'Rouke, 2003). We will also examine four specific business majors to further ascertain if the specific academic training in business might influence their perceptions on globalization.

Empirical studies have documented that more favorable attitudes towards globalization are found among college students, and specifically, these more favorable attitudes are found in business majors and those students with white-collar parents (Peng, 2001). Most Americans view globalization as positive for business, consumers and the economy, but somewhat negative in terms of job security and environment concerns. The magnitude of positive views appears to be falling. The Program on International Policy Attitudes (PIPA) asked a series of identical questions in 1999 and 2004, and noted a drop in favorable views. The German Marshall Fund also noted a plurality of respondents held a favorable view towards globalization, but the number expressing an 'extremely unfavorable view' was twice as large as the number expressing an 'extremely favorable' view ("Globalization," 2005). However, it must be noted that survey results are also driven by how the survey defines globalization. When globalization was defined as 'increasing connectivity' surveys have found an increasingly favorable view on globalization over similar time periods ("Views of a Changing World," 2003 and "Globalization," 2005). 
According to a recent (2004) survey conducted by Zogby International, 71 percent of Americans felt that the outsourcing of jobs hurt the US economy and 62 percent supported legislation that would restrict such practices. The majority of the respondents felt China poses the greatest threat. These results are in contrast to most economists who view protectionism as a threat to global economic development. Further, while individuals may see globalization resulting in positive effects for the economy, business and the consumer, attitudes concerning globalization's impact on the environment and domestic job creation and security may be quite different (www.americans-world.org).

The more recent 2007 Pew Survey on Global Attitudes towards globalization documented a waning of enthusiasm for globalization. Specifically, in both developing and developed countries, most people endorse free trade and markets, but the survey also found a strong link between the threats to a country's culture and traditions and a country's immigration fears. Even though the survey documented a significant decline in Western attitudes towards trade and less favorable views of multinationals, a large majority from all 47 nations surveyed believe international trade benefits their countries and the same majority still held a favorable attitude, though declining, toward the multinationals ("World Publics Welcome Global Trade", 2007). This finding was also consistent with an earlier 2006 PIPA poll of 20 countries that found a majority of respondents agreeing that the free market economy is the best system on which to base the future of the world, but there is a need for more government regulation of large companies to support consumer and worker rights and the environment. This favorable attitude toward the free market was highest among those with higher education and incomes ("20 Nation Poll..", 2006).

\section{METHODOLOGY AND MEASURES}

Our sample consisted of 557 upper-level (junior or senior) university students enrolled at a midwestern state university. Our intent was to contrast the various business majors, and also contrast the views of students majoring in business with the views of other majors on various aspects of globalization. Our two samples consisted of 303 students majoring in business and 254 students sampled from various liberal arts courses. Of the business majors, 95 selected finance as their primary major; 29 selected international business, 44 selected management, and 134 selected marketing. All students would have been exposed to similar general education courses during their first two years of study, and would have had exposure to many of their major course requirements by the time the survey was administered to them. Although each of the business major would have completed the same business core curriculum, specific courses in one's major, such as the curriculum offered in the International Business major, would more favorably influence one's attitudes towards globalization and these students are training for a more globally-oriented career. Further, Heckscher-Ohlin might argue that a particular major, more endowed with technical skills such as the Finance major, would have an influence on the globalization attitudes. Our study aims to provide clarification in this academic influence.

Students were surveyed with a set of questions which asked them to rate their degree of agreement or disagreement on a scale of 1 (Strongly Disagree) to 5 (Strongly Agree) to the various statements regarding globalization. The survey format first presented students with a set of questions to gauge their feelings regarding globalization's impact on the overall U.S. economy and firm profitability (questions 1 through 7). The second set of questions asks students to rate their beliefs regarding the global distribution of the benefits generated for the host country (questions 8 through 14). Lastly, we created a set of questions to have students rate their perceptions regarding the environmental, political and social byproducts of globalization (questions 15 through 26). Results of the survey are presented in the following section.

T-statistics for the difference between majors are calculated as:

$\mathrm{t}=\left[\mathrm{X}_{\mathrm{Mktg}}-\mathrm{X}_{\mathrm{Fin}}\right] / \sigma_{\text {difference }}$

where $\mathrm{X}$ represents the means of the respective samples and $\sigma_{\text {difference }}$ is the standard deviation of the difference between the two samples and is calculated as:

$\sigma_{\text {difference }}=\left\{\sigma^{2} *\left[1 / \mathrm{N}_{\text {Bus }}+1 / \mathrm{N}_{\text {NonBus }}\right]\right\}^{1 / 2}$ 
where $\sigma^{2}$ is the variance of the total sample and $\mathrm{N}$ is square root of the number of respondents in each sub-sample, with the sample separated into business and non-business majors.

\section{RESULTS}

Tables 1A, 1B and 1C present the student responses to the question groupings previously discussed: student attitudes on the global impact on the U.S. Economy (Table 1A), the host country (Table 1B), and general issues resulting from globalization (Table 1C). Results of Tables 1A, 1B and 1C are discussed in detail in the working paper, The Heckscher-Ohlin Theory: An Examination of Student Attitudes Toward Globalization (Janavaras, Kuzma and Thiewes, 2007) are presented in this paper only for comparison purposes to assist in contrasting the results found in the business major disciples. Mean responses with the standard deviation in parentheses to each of the questions are presented in the first two columns below. The difference between the two means is presented in the third column followed with the difference's t-statistic in parentheses.

Significant differences between business and non-business majors were found in virtually all of the questions. Only two of the questions failed to create significant differences in the responses at the .01 or higher significance level and all of the questions resulted in the business majors exhibiting more favorable (or less unfavorable) views on globalization relative to the non-business majors. Lastly, non-business majors exhibited a wider range of views, as evidenced by the larger standard deviations in the non-business student responses, on all but two of the questions.

Table 1A presents the results of student attitudes on globalization's impact on the U.S. economy. All differences between the two groups are significant at the .01 level of significance. Both groups of students agree that globalization benefits the U.S. economy, benefits U.S. consumers and encourages U.S. firms to invest abroad with the business students exhibiting the strongest agreement to these statements. Both groups tended to feel that globalization does not benefit U.S. workers or contribute much to the image of the U.S. around the world, with the non-business majors expressing the higher degree of negativity to this statement. It is interesting to note that the statement exhibiting the strongest disagreement between the two major groups in Table 1A concerned the statement that "Globalization has a positive impact on the overall growth of the US economy."

Table 1A

Student Attitudes on Globalization's Impact on the U.S. Economy Contrasting Business with Liberal Arts Majors

\begin{tabular}{|c|c|c|c|}
\hline & $\begin{array}{l}\text { Business } \\
(\mathrm{N}=303) \\
\text { Mean (SD) }\end{array}$ & $\begin{array}{l}\text { Non-Bus } \\
(\mathrm{N}=254) \\
\text { Mean (SD) }\end{array}$ & $\begin{array}{l}\text { Difference } \\
\text { (t-stat) }\end{array}$ \\
\hline 1. Globalization has a positive impact on the overall growth of the US economy & $3.98(.78)$ & $3.38(1.02)$ & $.60(7.42)^{*}$ \\
\hline 2. Globalization benefits US consumers. & $4.20(.74)$ & $3.65(.99)$ & $.55(7.18)^{*}$ \\
\hline 3. Globalization benefits US workers and contributes to job creation in the US. & $3.20(1.00)$ & $2.70(1.10)$ & $.50(5.42)^{*}$ \\
\hline 4. Globalization encourages US firms to invest in foreign countries. & $4.25(.73)$ & $3.92(.84)$ & $.33(4.86) *$ \\
\hline 5. Globalization encourages foreign companies to invest in the US. & $3.81(.95)$ & $3.22(1.04)$ & $.59(6.71)^{*}$ \\
\hline $\begin{array}{l}\text { 6. Globalization enhances the profitability of US based multinational } \\
\text { corporations. }\end{array}$ & $4.09(.80)$ & $3.79(.92)$ & $.31(4.16)^{*}$ \\
\hline $\begin{array}{l}\text { 7. Globalization enhances the profitability of foreign companies operating in the } \\
\text { US. }\end{array}$ & $3.80(.86)$ & $3.37(0.95)$ & $.43(5.45)^{*}$ \\
\hline $\begin{array}{l}\text { 8. Globalization has contributed to the improvement of the US image around the } \\
\text { world. }\end{array}$ & $3.17(.94)$ & $2.62(1.10)$ & $.55(6.19)^{*}$ \\
\hline
\end{tabular}

1=Strongly Disagree, 2=Somewhat Disagree, 3=Neutral, 4=Somewhat Agree, 5=Strongly Agree.

*.01 significance; ${ }^{*} .05$ significance 
Table 1B

Student Attitudes on Globalization's Impact on the Host Countries Contrasting Business with Liberal Arts Majors

\begin{tabular}{|c|c|c|c|}
\hline & $\begin{array}{c}\text { Business } \\
(\mathrm{N}=303) \\
\text { Mean (SD) }\end{array}$ & $\begin{array}{c}\text { Non-Bus } \\
(\mathrm{N}=254) \\
\text { Mean (SD) } \\
\end{array}$ & $\begin{array}{l}\text { Difference } \\
\text { (t-stat) }\end{array}$ \\
\hline $\begin{array}{l}\text { 9. Globalization has benefited all countries around the world, although some } \\
\text { countries may benefit more than others. }\end{array}$ & $3.56(1.01)$ & $2.94(1.21)$ & $.62(6.33)^{*}$ \\
\hline 10. Globalization is more beneficial to the more developed countries. & $3.67(.99)$ & $3.67(1.16)$ & $.0(.01)$ \\
\hline 11. Globalization is more beneficial to the less developed countries. & $2.86(1.07)$ & $2.61(1.15)$ & $.25(2.60)^{*}$ \\
\hline 12. Globalization benefits consumers around the World. & $3.93(.75)$ & $3.35(1.00)$ & $.58(7.40)^{*}$ \\
\hline 13. Globalization benefits workers around the World. & $3.42(.90)$ & $2.88(1.10)$ & $.54(6.18)^{*}$ \\
\hline $\begin{array}{l}\text { 14. The overall negative consequences of globalization outweigh the overall } \\
\text { benefits of globalization. }\end{array}$ & $2.60(1.04)$ & $2.94(1.07)$ & $-.30(-3.70)$ \\
\hline
\end{tabular}

1=Strongly Disagree, 2=Somewhat Disagree, 3=Neutral, 4=Somewhat Agree, 5=Strongly Agree.

*.01 significance; ${ }^{\#} .05$ significance

Table 1C

Student Attitudes on General Global Issues Contrasting Business with Liberal Arts Majors

\begin{tabular}{|c|c|c|c|}
\hline & $\begin{array}{l}\text { Business } \\
(\mathrm{N}=303) \\
\text { Mean (SD) }\end{array}$ & $\begin{array}{l}\text { Non-Bus } \\
(\mathrm{N}=254) \\
\text { Mean (SD) }\end{array}$ & $\begin{array}{l}\text { Difference } \\
\text { (t-stat) }\end{array}$ \\
\hline 15. Globalization has contributed to global warming. & $2.73(1.14)$ & $3.25(1.178)$ & $-.52(-5.20)^{*}$ \\
\hline 16. Globalization is responsible for environmental degradation. & $2.81(.99)$ & $3.41(1.07)$ & $-.60(-6.63) *$ \\
\hline $\begin{array}{l}\text { 17. Globalization has fueled terrorism because of the economic disparities it } \\
\text { has helped to create among poor countries. }\end{array}$ & $2.82(.99)$ & $3.20(1.09)$ & $-.38(-4.25)^{*}$ \\
\hline 18. Globalization has contributed to the rise of corruption around the world. & $2.86(.97)$ & $3.30(1.04)$ & $-.44(-5.04)^{*}$ \\
\hline $\begin{array}{l}\text { 19. Globalization is used by developed nations in an attempt to exploit the } \\
\text { natural resources of the less developed countries around the world. }\end{array}$ & $2.97(.96)$ & $3.41(1.09)$ & $-.40(4.90)^{*}$ \\
\hline $\begin{array}{l}\text { 20. Globalization has contributed to the elimination of trade and investment } \\
\text { barriers and the lowering of prices on goods and services around the world. }\end{array}$ & $3.66(.90)$ & $3.32(.94)$ & $.34(4.28)^{*}$ \\
\hline $\begin{array}{l}\text { 21. Globalization has made travel and communications easier and more cost } \\
\text { effective. }\end{array}$ & $4.00(.90)$ & $3.60(.90)$ & $.30(4.50)^{*}$ \\
\hline $\begin{array}{l}\text { 22. Globalization has contributed to increasing the economic gap between } \\
\text { developed and other countries. }\end{array}$ & $3.31(.90)$ & $3.44(1.02)$ & $-.10(-1.70)$ \\
\hline $\begin{array}{l}\text { 23. Efforts should be made and appropriate measures should be taken by the } \\
\text { nations' governments to stop the globalization process from spreading any } \\
\text { further in the future. }\end{array}$ & $2.23(1.17)$ & $2.82(1.01)$ & $-.58(-6.06)^{*}$ \\
\hline 24. The process of globalization is here to stay for the years to come. & $4.31(.79)$ & $3.81(.90)$ & $-.50(6.66)^{*}$ \\
\hline $\begin{array}{l}\text { 25. Having a destabilizing effect on the political stability of less developed } \\
\text { countries and emerging markets. }\end{array}$ & $2.95(.65)$ & $3.11(.85)$ & $-.17(-2.63)^{*}$ \\
\hline 26. The recurrent protests against globalization are justified. & $2.67(.84)$ & $3.19(.99)$ & $-.50(-6.50)^{*}$ \\
\hline
\end{tabular}

1=Strongly Disagree, 2=Somewhat Disagree, 3=Neutral, 4=Somewhat Agree, 5=Strongly Agree.

*.01 significance; ${ }^{*} .05$ significance

Table 1B examines differences in the student attitudes regarding globalization's impact on the host country. No significant differences were found between students when asked whether globalization would be more beneficial to the less or more developed countries, but all other questions concerning the impact on the host country were significant at the .01 level. A significantly higher percentage of business students felt that all countries, their workers and consumers would benefit from globalization. 
Student attitudes on a broad list of global issues are presented in Table 1C. Many of the responses resulted in average ratings that were somewhat neutral, but all but one of the differences were significant at the .01 level and again, in no case were the non-business students more favorable to globalization issues than the business students. Strong differences in perceptions were documented when students were asked about globalization contribution to global warming, environmental degradation, globalization's fueling of terrorism and its contribution to corruption. The less positive view of the non-business majors toward globalization is also reflected in the final set of questions which finds stronger agreement among non-business majors that the recurrent protests against globalization are justified.

Tables 2A, 2B and 2C present the average responses of the four business majors on the same set of questions analyzed in Tables $1 \mathrm{~A}, 1 \mathrm{~B}$ and $1 \mathrm{C}$. The major resulting in the highest ranking of each question was compared with the major resulting in the lowest ranking of that question. The major with the highest and lowest ranking is provided in parentheses in each of the rating cells. The far right column provides the response difference between the two majors and the differences t-statistic in parentheses.

Table 2A

Business Majors Attitudes on Globalization's Impact on the U.S. Economy Contrasting the highest to lowest ranking by major

\begin{tabular}{|c|c|c|c|}
\hline & $\begin{array}{l}\text { Highest } \\
\text { Question } \\
\text { Rating } \\
\text { (Major) }\end{array}$ & $\begin{array}{l}\text { Lowest } \\
\text { Question } \\
\text { Rating } \\
\text { (Major) }\end{array}$ & $\begin{array}{l}\text { Difference } \\
\text { (t-stat) }\end{array}$ \\
\hline $\begin{array}{l}\text { 1. Globalization has a positive impact on the overall growth of the US } \\
\text { economy. }\end{array}$ & $\begin{array}{c}4.17 \\
\text { (InterBus) }\end{array}$ & $\begin{array}{c}3.79 \\
\text { (Finance) }\end{array}$ & $\begin{array}{c}.38 \\
(2.31)^{\#}\end{array}$ \\
\hline 2. Globalization benefits US consumers. & $\begin{array}{c}4.24 \\
\text { (Finance) }\end{array}$ & $\begin{array}{c}4.14 \\
\text { (InterBus) }\end{array}$ & $\begin{array}{c}.10 \\
(0.50)\end{array}$ \\
\hline $\begin{array}{l}\text { 3. Globalization benefits US workers and contributes to job creation in the } \\
\text { US. }\end{array}$ & $\begin{array}{c}3.37 \\
\text { (Marketing) }\end{array}$ & $\begin{array}{c}2.91 \\
\text { (Management) }\end{array}$ & $\begin{array}{c}.46 \\
(2.65)^{\#}\end{array}$ \\
\hline 4. Globalization encourages US firms to invest in foreign countries. & $\begin{array}{c}4.38 \\
\text { (InterBus) }\end{array}$ & $\begin{array}{c}4.16 \\
\text { (Finance) }\end{array}$ & $\begin{array}{c}.22 \\
(1.41)\end{array}$ \\
\hline 5. Globalization encourages foreign companies to invest in the US. & $\begin{array}{c}3.90 \\
\text { (InterBus) }\end{array}$ & $\begin{array}{c}3.60 \\
\text { (Management) }\end{array}$ & $\begin{array}{c}.30 \\
(1.32)\end{array}$ \\
\hline $\begin{array}{l}\text { 6. Globalization enhances the profitability of US based multinational } \\
\text { corporations. }\end{array}$ & $\begin{array}{c}4.28 \\
\text { (InterBus) }\end{array}$ & $\begin{array}{c}4.03 \\
\text { (Finance) }\end{array}$ & $\begin{array}{c}.25 \\
(1.44)\end{array}$ \\
\hline $\begin{array}{l}\text { 7. Globalization enhances the profitability of foreign companies operating } \\
\text { in the US. }\end{array}$ & $\begin{array}{c}4.04 \\
\text { (InterBus) }\end{array}$ & $\begin{array}{c}3.74 \\
\text { (Marketing) }\end{array}$ & $\begin{array}{l}.29 \\
(1.67)\end{array}$ \\
\hline $\begin{array}{l}\text { 8. Globalization has contributed to the improvement of the US image } \\
\text { around the world. }\end{array}$ & $\begin{array}{c}3.24 \\
\text { (Marketing) }\end{array}$ & $\begin{array}{c}3.00 \\
\text { (InterBus) }\end{array}$ & $\begin{array}{c}.24 \\
(1.27)\end{array}$ \\
\hline
\end{tabular}

1=Strongly Disagree, 2=Somewhat Disagree, 3=Neutral, 4=Somewhat Agree, 5=Strongly Agree.

*.01 significance; ${ }^{\#} .05$ significance

Of overall note, is that 24 of the 26 average response differences between the business and non-business majors were significant at the .01 level. However, unlike the differences between the business and non-business majors, none of the rating differences between the business majors were significant at the .01 level. Five of the 26 rating differences were significant at the .05 level, while 21 rating differences failed to exhibit statistical significance at the .05 level. Also, as the tables indicate, no specific major consistently stood out as more of less favorable on the various globalization questions. 
Table 2B

Business Majors Attitudes on Globalization's Impact on the Host Countries Contrasting the highest to lowest ranking by major

\begin{tabular}{|c|c|c|c|}
\hline & $\begin{array}{l}\text { Highest } \\
\text { Question } \\
\text { Rating } \\
\text { (Major) }\end{array}$ & $\begin{array}{l}\text { Lowest } \\
\text { Question } \\
\text { Rating } \\
\text { (Major) }\end{array}$ & $\begin{array}{l}\text { Difference } \\
\text { (t-stat) }\end{array}$ \\
\hline $\begin{array}{l}\text { 9. Globalization has benefited all countries around the world, although } \\
\text { some countries may benefit more than others. }\end{array}$ & $\begin{array}{c}3.64 \\
\text { (Management) } \\
\end{array}$ & $\begin{array}{c}3.41 \\
\text { (InterBus) } \\
\end{array}$ & $\begin{array}{c}.22 \\
(1.04)\end{array}$ \\
\hline 10. Globalization is more beneficial to the more developed countries. & $\begin{array}{c}3.97 \\
\text { (InterBus) } \\
\end{array}$ & $\begin{array}{c}3.43 \\
\text { (Finance) }\end{array}$ & $\begin{array}{c}.54 \\
(2.57)^{\#}\end{array}$ \\
\hline 11. Globalization is more beneficial to the less developed countries. & $\begin{array}{c}3.00 \\
\text { (Management) }\end{array}$ & $\begin{array}{c}2.74 \\
\text { (Marketing) } \\
\end{array}$ & $\begin{array}{c}.26 \\
(1.18)\end{array}$ \\
\hline 12. Globalization benefits consumers around the World. & $\begin{array}{c}3.98 \\
\text { (Finance) } \\
\end{array}$ & $\begin{array}{c}3.90 \\
\text { (Marketing) } \\
\end{array}$ & $\begin{array}{c}.08 \\
(0.76) \\
\end{array}$ \\
\hline 13. Globalization benefits workers around the World. & $\begin{array}{c}3.49 \\
\text { (Management) } \\
\end{array}$ & $\begin{array}{c}3.27 \\
\text { (InterBus) } \\
\end{array}$ & $\begin{array}{c}.22 \\
(1.02) \\
\end{array}$ \\
\hline $\begin{array}{l}\text { 14. The overall negative consequences of globalization outweigh the } \\
\text { overall benefits of globalization. }\end{array}$ & $\begin{array}{c}2.72 \\
\text { (InterBus) }\end{array}$ & $\begin{array}{c}2.48 \\
\text { (InterBus) }\end{array}$ & $\begin{array}{c}.25 \\
(1.11)\end{array}$ \\
\hline
\end{tabular}

1=Strongly Disagree, 2=Somewhat Disagree, 3=Neutral, 4=Somewhat Agree, 5=Strongly Agree.

*.01 significance; ${ }^{*} .05$ significance

The examination of Table $2 \mathrm{~A}$ reveals that the only significant disagreement between the business majors is found in questions 1 and 3, but all business majors, with international business majors holding the highest rating, did feel globalization provided a positive impact on the US economy. Regarding globalization's benefits to workers, business majors were more neutral but the management majors exhibited a slightly lower rating in their responses on this question. No other significant differences on any of questions concerning globalization's impact on the U.S. economy were documented.

Questions concerning the attitudes on globalization's impact on the host countries also indicated a lack of significant differences between students of the four business disciplines. Only question 10 revealed a significant difference between the International Business and Finance majors, with International Business majors having a stronger belief that globalization is more beneficial to the more developed countries.

Lastly, there was also overall agreement between the four disciplines on the set of questions attempting to measure student attitudes on general global issues. The only significant differences found that the international business majors had a stronger feeling that globalization is responsible for environmental degradation and contributed to the rise of corruption around the world. All major averages generally disagreed with the statement that the recurrent protests against globalization are justified and were in virtual identical and strong agreement that globalization is here to stay for the years to come.

It might be argued that business majors are engaged in studying business, and as such, would be more favorable to the business and economic results of globalization. This favorable attitude might result from the business training and may not be caused by the level of student skill endowments as suggested by the HeckscherOhlin theory. Janavaras, Kuzma and Thiewes (2007) separately analyzed a group of electrical engineering majors. These majors would have comparable general educational backgrounds, would lack the business training taken by the business majors but would possess highly technical or skilled training relative to the other majors.

When responses of electrical engineering majors were compared with those of the business majors, 19 of the 26 average responses revealed no significant differences between the two student groups at the .05 level or above, providing further evidence that the level of skill endowments have a strong influence on student globalization attitudes. 
Table 2C

Business Majors Attitudes on General Global Issues

Contrasting the highest to lowest ranking by major

\begin{tabular}{|c|c|c|c|}
\hline & $\begin{array}{l}\text { Highest } \\
\text { Question } \\
\text { Ranking } \\
\text { (Major) }\end{array}$ & $\begin{array}{l}\text { Lowest } \\
\text { Question } \\
\text { Rating } \\
\text { (Major) }\end{array}$ & $\begin{array}{l}\text { Difference } \\
(\mathrm{t}-\mathrm{stat})\end{array}$ \\
\hline 15. Globalization has contributed to global warming. & $\begin{array}{c}3.11 \\
\text { (InterBus) }\end{array}$ & $\begin{array}{c}2.67 \\
\text { (Finance) }\end{array}$ & $\begin{array}{c}.44 \\
(1.88)\end{array}$ \\
\hline 16. Globalization is responsible for environmental degradation. & $\begin{array}{c}3.14 \\
\text { (InterBus) }\end{array}$ & $\begin{array}{c}2.76 \\
\text { (Marketing) } \\
\end{array}$ & $\begin{array}{c}.38 \\
(1.85)\end{array}$ \\
\hline $\begin{array}{l}\text { 17. Globalization has fueled terrorism because of the economic } \\
\text { disparities it has helped to create among poor countries. }\end{array}$ & $\begin{array}{c}3.24 \\
\text { (InterBus) }\end{array}$ & $\begin{array}{c}2.77 \\
\text { (Management) }\end{array}$ & $\begin{array}{c}.47 \\
(2.25)^{\#}\end{array}$ \\
\hline $\begin{array}{l}\text { 18. Globalization has contributed to the rise of corruption around the } \\
\text { world. }\end{array}$ & $\begin{array}{c}3.04 \\
\text { (InterBus) }\end{array}$ & $\begin{array}{c}2.73 \\
\text { (Management) }\end{array}$ & $\begin{array}{c}.31 \\
(1.50)\end{array}$ \\
\hline $\begin{array}{l}\text { 19. Globalization is used by developed nations in an attempt to exploit } \\
\text { the natural resources of the less developed countries around the } \\
\text { world. }\end{array}$ & $\begin{array}{c}3.35 \\
\text { (InterBus) }\end{array}$ & $\begin{array}{c}2.90 \\
\text { (Marketing) }\end{array}$ & $\begin{array}{c}.45 \\
(2.28)^{\#}\end{array}$ \\
\hline $\begin{array}{l}\text { 20. Globalization has contributed to the elimination of trade and } \\
\text { investment barriers and the lowering of prices on goods and services } \\
\text { around the world. }\end{array}$ & $\begin{array}{c}3.80 \\
\text { (Finance) }\end{array}$ & $\begin{array}{c}3.56 \\
\text { (Marketing) }\end{array}$ & $\begin{array}{c}.24 \\
(1.97)\end{array}$ \\
\hline $\begin{array}{l}\text { 21. Globalization has made travel and communications easier and more } \\
\text { cost effective. }\end{array}$ & $\begin{array}{c}4.24 \\
\text { (InterBus) } \\
\end{array}$ & $\begin{array}{c}3.92 \\
\text { (Marketing) } \\
\end{array}$ & $\begin{array}{c}.32 \\
(1.79) \\
\end{array}$ \\
\hline $\begin{array}{l}\text { 22. Globalization has contributed to increasing the economic gap } \\
\text { between developed and other countries. }\end{array}$ & $\begin{array}{c}3.36 \\
\text { (Management) }\end{array}$ & $\begin{array}{c}3.26 \\
\text { (Finance) }\end{array}$ & $\begin{array}{c}.05 \\
(0.32)\end{array}$ \\
\hline $\begin{array}{l}\text { 23. Efforts should be made and appropriate measures should be taken by } \\
\text { the nations' governments to stop the globalization process from } \\
\text { spreading any further in the future. }\end{array}$ & $\begin{array}{c}2.30 \\
\text { (Management) }\end{array}$ & $\begin{array}{c}2.16 \\
\text { (Finance) }\end{array}$ & $\begin{array}{l}.14 \\
(.64)\end{array}$ \\
\hline 24. The process of globalization is here to stay for the years to come. & $\begin{array}{c}4.36 \\
\text { (Management) } \\
\end{array}$ & $\begin{array}{c}4.20 \\
\text { (Finance) } \\
\end{array}$ & $\begin{array}{c}.16 \\
(1.13) \\
\end{array}$ \\
\hline $\begin{array}{l}\text { 25. Having a destabilizing effect on the political stability of less } \\
\text { developed countries and emerging markets. }\end{array}$ & $\begin{array}{c}3.00 \\
\text { (InterBus) } \\
\end{array}$ & $\begin{array}{c}2.84 \\
\text { (Management) }\end{array}$ & $\begin{array}{c}.16 \\
(1.02)\end{array}$ \\
\hline 26. The recurrent protests against globalization are justified. & $\begin{array}{c}2.82 \\
\text { (Management) } \\
\end{array}$ & $\begin{array}{c}2.60 \\
\text { (Finance) } \\
\end{array}$ & $\begin{array}{c}.22 \\
(1.23)\end{array}$ \\
\hline
\end{tabular}

1=Strongly Disagree, 2=Somewhat Disagree, 3=Neutral, 4=Somewhat Agree, 5=Strongly Agree.

*.01 significance; ${ }^{\#} .05$ significance

\section{CONCLUSIONS}

We surveyed student attitudes on a set of 26 questions which related to three separate issues: 1) globalization's impact on the U.S. Economy, 2) globalization's impact on the host country, and 3) general issues resulting from globalization, such as corruption, pollution and political stability. A comparison of business majors with liberal arts majors found that business majors were more favorable than liberal arts majors on all of various questions asked concerning their views on globalization. All but two of the 26 differences in the survey questions were significant at the .01 level.

The Heckscher-Ohlin theory postulates that skilled individuals from skill-endowed nations would be more open to globalization and the extension of the theory hypothesizes that the same openness to globalization would be exhibited in individual attitudes based on the level of skills attained in one's education. An analysis of the four specific business disciplines within the business majors - finance, international business, management and marketing - resulted in no consistent differences as found in the comparison of the business and liberal arts majors. A comparison of the responses of the specific discipline which exhibited the most favorable response to the discipline which exhibited the least favorable response, unlike the business and liberal arts comparison, revealed that none of the differences were significant at the .01 level. Only five of the 26 questions exhibited statistical significance at the 
.05 level. Further, no specific discipline in the business major exhibited consistently more or less favorable attitudes on globalization.

One of the goals of most universities is to prepare students to be responsible citizens in a global environment. We would argue that a necessary condition to support this goal is to provide students with the necessary skills to compete in this environment. Research cited in this paper has noted various factors that contribute to the varied perceptions on globalization. Student globalization attitudes would also be influenced by a variety of factors in addition to a majors' content or skill level, such as the emphasis, methodology or opinions particular faculty might prefer to place on events concerning globalization. However, if it is the mission of university education to develop responsible citizens in a global environment, faculty should be aware of how the academic environment influences student attitudes toward globalization. Although both business and liberal arts majors are exposed to similar general education courses in their first two years of academic study, students in these two areas of study exhibited significant differences in their attitudes concerning globalization in their junior and senior years, the period in which students would be more engaged in studying in courses in their major area of interest. While most business schools require a common core of business foundation courses, the four specific disciplines investigated in our study each teach a different set of skills. However, most of the comparisons among the 26 questions found general, and more favorable, agreement on globalization issues among the four business disciplines than the comparison with the liberal arts majors.

\section{REFERENCES}

1. Annan, Kofi, Secretary-General of the United Nations, addressing the Millennium Form on 22 May 2000 (cited in Standing up for the Global Economy, International Chamber of Commerce, www.iccwbo.org.

2. Bernstein, A. (2000). Backlash Against Globalization. Business Week, April 24, 43.

3. Bowen, Harry, Edward E. Leamer and Leo Sveikauskas (1987). Multicountry, Multifactor Tests of the Factor Abundance Theory. American Economic Review, 77, 791-809.

4. Davis, Donald R. and David E. Weinstein (2001). An Account of Global Factor Trade. American Economic Review, 91: 1423-1453.

5. __ (2005) Globalization. World Public Opinion.org, available at www.americans-world.org/digest/ global issues/globalization/general.cfm.

6. Hilsenrath, Jon E. (2002). Globalization Gets Mixed Grades in U.S. Universities. Wall Street Journal, December 2.

7. Janavaras, Basil, John Kuzma and Harold Thiewes (2007). The Heckscher-Ohlin Theory: An Examination of Student Attitudes Toward Globalization. Working Paper 2007, College of Business, Minnesota State University, Mankato.

8. Kassum, Julian (2004), Standing Up for the World Economy. ICC's Corporate Economists Advisory Group for the ICC $35^{\text {th }}$ World Congress, available at www.iccwbo.org.

9. O'Rourke, Kevin H (2003). Heckscher-Ohlin Theory and Individual Attitudes Towards Globalization. IIIS Discussion Paper No. 7, Trininty College, Dublin 2, Ireland.

10. Peng, Mike W. and Hyung-Deok Shin (2001). How Do Future Business Leaders View Globalization? Working Paper March 2001, Fisher College of Business, The Ohio State University.

11. Scheve, Kenneth F. and Matthew J. Slaughter (2001). What Determines Individual Trade-Policy Preferences? Journal of International Economics, 54, 267-292.

12. Stiglitz, Joseph (2002). Globalization and Its Discontents. WW Norton and Company: New York.

13. (2006) 20 Nation Poll Finds Strong Global Consensus: Support for Free Market System, But also More Regulation of Large Companies. available at www.worldpublicopinion.org/articles/btglobalizationtradera.

14. (2003). Views of a Changing World. Pew Research Center for the People and the Press, Washington, D.C., available at http://pewglobal.org/reports.

15. _ (2007). World Publics Welcome Global Trade - But Not Immigration: 47-Nation Pew Global Attitudes Survey. Pew Research Center for the People and the Press, Washington, D.C., available at http://pewglobal.org/.

16. (2004). www.zolby.com/news/ReadNews.dbm?ID=870. 
NOTES 